Ksonzhyk Iryna, Doctor of Economics, Professor, Professor of Department of Accounting and Taxation, Mykolayiv National Agrarian University, Mykolayiv, Ukraine

ORCID ID: 0000-0001-5172-3821

e-mail: ksonzhyk@mnau.edu.ua

Pisochenko Tetiana, Candidate of Economic Sciences, Assistant, Mykolayiv National Agrarian University, Mykolayiv, Ukraine

ORCID ID: 0000-0001 5647-8167

e-mail: pisochenko@mnau.edu.ua

Petrov Pavel, candidate for a master's degree, Mykolayiv National Agrarian University, Mykolayiv, Ukraine e-mail: 3p@ukr.net

\title{
Organizational and Legal Regulation of Accounting of Business Trip Expenses of Employees of Public Sector Institutions of Ukraine
}

\begin{abstract}
Introduction. The public sector of Ukraine at the present stage of its historical development is constantly transforming, cooperating with many countries of the world in various fields, adopting their experience of the state formation. Therefore, in order to ensure an effective solution to the issues of successful functioning of public sector entities, there is a need for business trips both on the territory of Ukraine and abroad. At the same time, both heads of public enterprises and institutions and ordinary workers can be sent on a business trip.

Purpose. The goal of the research is to analyze the organizational and legal foundations and scientific and methodological positions regarding business trips, accounting for the costs for their implementation and documenting this process in institutions and at public sector enterprises.

Results. The article examines the list of documents that are made to document business trips and identifies the specifics of reporting on receipt of funds. The requirements for documents added to the report on the use of funds provided for a business trip or on condition of accountability have been determined. The features of the procedure for reflecting expenses in accounting and tax accounting have been considered. The introduction of the performance audit mechanism has been proposed as a progressive source of control over the use of public funds.

Conclusions. Absolute and timely documentation of the accounting of business trip expenses within the framework of regulatory legal acts is a guarantee of compliance with accounting policies, reliability of accounting and reporting, accounting for settlements with accountable persons. In order to minimize travel expenses and make the most efficient use of financial resources, institutions operating in the public sector are in dire need of a performance audit mechanism.
\end{abstract}

Keywords: business trips; accountable persons; advance payment; business trip expense report; per diem expenses; reporting deadlines; performance audit.

Удк 651.92:3321

Ксьонжик I. В., доктор економічних наук, професор, професор кафедри обліку і оподаткування, Миколаївський національний аграрний університет, Миколаїв, Україна

Пісоченко Т.С., кандидат економічних наук, асистент кафедри обліку i оподаткування, Миколаївський національний аграрний університет, Миколаїв, Україна Україна

Петров П. П., здобувач вищої освіти, Миколаївський національний аграрний університет, Миколаїв,

\section{Організаційно-правове регулювання обліку витрат на відрядження працівників установ державного сектору України}

Анотація. Державний сектор України на сучасному етапі свого історичного розвитку постійно трансформується, співпрацюючи з багатьма країнами світу у різних сферах, переймаючи їх досвід державотворення. Для забезпечення ефективного вирішення питань успішного функціонування суб'єктів державного сектору виникає необхідність у службових відрядженнях як по території України, так і за кордон. При цьому у відрядження можуть бути відправлені як керівники державних підприємств і установ, так і пересічні працівники.

Метою дослідження $\epsilon$ аналіз організаційно-правових засад й науково-методичних позицій щодо службових відряджень, обліку витрат на їх здійснення та документального забезпечення цього процесу в установах $і$ на підприємствах державного сектору.

У статті досліджено перелік документів, які складають для документування службових поїдок, та визначено специбіку звітування за отриманні кошти. Визначено вимоги до документів, які додають до звіту про використання коштів, наданих на відрядження або під звіт. Розглянуто особливості порядку відображення витрат на відрядження в

Стаття надійшла до редакції: 15.01.2021

Received: 15 January 2021 
бухгалтерському й податковому обліку. Абсолютне і вчасне документування обліку витрат на відрядження в рамках нормативно-правових актів є гарантією дотримання облікової політики, достовірності обліку та звітності, обліку розрахунку з підзвітними особами. Для мінімізації витрат на відрядження та якомога ефективнішого використання фінансових ресурсів, перед установами, що працюють в державному секторі, постає гостра потреба у запровадженні механізму аудиту ефективності. звітування.

Ключові слова: відрядження; підзвітні особи; аванс; звіт про використання коштів у відрядженні; добові; строки

Formulation of the problem. The public sector of Ukraine at the present stage of its historical development is constantly transforming, cooperating with many countries of the world in various fields, adopting their experience of the state formation. Therefore, in order to ensure an effective solution to the issues of successful functioning of public sector entities, there is a need for business trips both on the territory of Ukraine and abroad. At the same time, both heads of public enterprises and institutions and ordinary workers can be sent on a business trip.

Organizational and legal as well as accounting support for the process of sending civil servants on a business trip, constant changes in domestic budget and tax legislation, a specific procedure for the formation and accounting of expenses provide for the documentary registration of a significant number of business transactions and require indepth research. This is due to the fact that the main goal of public sector entities in accounting and control of expenditures is the need to increase the quality and reliability of accounting information in matters of the expenditure part of the budget, transparency in the use of public financial resources, as well as full coverage of data on the institution's expenses in reporting and ensuring conditions for conducting their analysis.

Analysis of recent research and publications. The problems of organization and reforming of accounting in public sector institutions were considered in the scientific works of such scientists as S. V. Svirko [1], P. Y. Atamas [2], M. B. Luchko [3], N. Khorunzhak [4], S. Sysiuk [5], R. Dzhoha [6] and others. Issues of accounting and taxation of business trip expenses of a public sector entity, within Ukraine and abroad, have become the subject of research by economists such as: M. T. Bilukha [7], T. T. Duda [8], M. S. Len [9], N. B. Melnyk [10], and others. However, this problematics require further research, given the legal specifics of current legislation regarding the object of study.

Formulation of research goals. The goal of the research is to analyze the organizational and legal foundations and scientific and methodological positions regarding business trips, accounting for the costs for their implementation and documenting this process in institutions and at public sector enterprises.

Outline of the main research material. A business trip is considered to be a trip of an employee according to the order of the head of the institution for a certain period of time to another locality to carry out an official assignment outside the place of permanent work [11].

The provisions of the Instruction apply only to public authorities, enterprises, institutions and organizations which are fully or partially supported by budgetary funds. For other enterprises and institutions, this instruction is only advisory in nature.

Sending a civil servant on a business trip is carried out by the head of a public enterprise, institution or organization. The management of an enterprise in the public sector needs to send an employee on a business trip, observing all possible legal norms, which are formed by the following regulatory legal acts:

1. Code of Labor Laws of Ukraine [12].

2. The Law of Ukraine "On Public Service" [13].

3. Resolution of the Cabinet of Ministers "On the amounts and composition of business trip expenses of civil servants, as well as other persons sent on a business trip by enterprises, institutions and organizations, which are fully or partially supported (financed) from budget funds [14].

4. Instruction on business trips within Ukraine and abroad [11].

Therefore, a public institution draws up an order (decree) on the employee's business trip, indicating: destination; name of the enterprise or institution where the employee is sent; term and purpose of the trip.

The term of a business trip is determined by the head or his/her deputy (the term of a business trip of a civil servant is determined by the head of the civil service), but cannot exceed 30 calendar days. Determination of the number of days of a business trip for the per diem expenses paymentis carried out taking into account the day of departure on a business trip and the day of arrival at the place of permanent work.

When determining the candidacy of an employee who will be sent on a business trip, it must be remembered that certain categories of civil servants, according to labor legislation, are prohibited from being sent on business trips. And individual workers can be sent only if certain conditions are met (Table 1).

In addition, it is prohibited to send an employee on business trips during the period of his/her temporary disability. Indeed, according to the current legislation, for the period of illness, the employee is provided with a certificate of incapacity for work, which is the basis for dismissal from work. Therefore, there are no legal grounds for attracting an employee to carry out a service assignment during a period of temporary disability $[17,18]$. At the same time, if, in violation of the current legislation, the employer sent a sick employee on a business trip, he is obliged to reimburse such an employee for travel, accommodation and per diem expenses. 
Електронне наукове фахове видання з економічних наук “Modern Economics», №25 (2021), 86-91 https://modecon.mnau.edu.ua | ISSN 2521-6392

Table 1.Restriction to a business trip

\begin{tabular}{|c|c|c|c|}
\hline No. & $\begin{array}{l}\text { Categories } \\
\text { of employees }\end{array}$ & $\begin{array}{l}\text { Article of } \\
\text { the Code } \\
\text { of Labor } \\
\text { Laws }\end{array}$ & Comments \\
\hline 1. & $\begin{array}{l}\text { Pregnant women and } \\
\text { women with children } \\
\text { under } 3 \text { years }\end{array}$ & Art. 176 & $\begin{array}{l}\text { There is a complete ban on business trips for this category. And the } \\
\text { employer should not concern about the desire of the employee herself in } \\
\text { this case. Even after receiving a statement from an employee about her } \\
\text { desire to go on a business trip, the employer cannot send her on a } \\
\text { business trip. Violation of this prescription can lead to undesirable } \\
\text { consequences, namely: } \\
\text { - an administrative fine imposed on the employer - private entity and } \\
\text { officials of the employer - legal entity in accordance with parts } 1 \text { and } 2 \text { of } \\
\text { Art. } 41 \text { of the Code of Ukraine on Administrative Offenses [15]; } \\
\text { - a fine imposed on the employer in accordance with Art. } 265 \text { of the Code } \\
\text { of Labor Laws [12]. }\end{array}$ \\
\hline 2. & $\begin{array}{l}\text { Women with children } \\
\text { between the ages of } 3 \text { and } \\
14 \text { or children with } \\
\text { disabilities }\end{array}$ & Art. 177 & $\begin{array}{l}\text { For such workers, incomplete restrictions apply. So, they can be sent on a } \\
\text { business trip if the following conditions are met: } \\
\text { - written consent for a business trip was obtained from them; } \\
\text { - they are familiar with the right to refuse a business trip *. } \\
\text { Failure to comply with the listed requirements can also lead to fines (see } \\
\text { clause } 1 \text { of this table) }\end{array}$ \\
\hline 3. & $\begin{array}{l}\text { Fathers raising children } \\
\text { without a mother (including } \\
\text { in the case of a mother's long } \\
\text { stay in a medical institution), } \\
\text { as well as guardians } \\
\text { (trustees), one of the } \\
\text { adoptive parents, one of the } \\
\text { parent-educators }\end{array}$ & Art. 1861 & $\begin{array}{l}\text { These categories of workers are subject to the guarantees specified in } \\
\text { paragraphs } 1 \text { and } 2 \text { of this table depending on the age of the child }\end{array}$ \\
\hline
\end{tabular}

Source: [16]

At the same time, in the timesheet for the period of a business trip, such an employee should indicate "BT" or "07" (business trip), and not "TD" or "26" (paid temporary disability). Indeed, according to Art. 121 of the Code of Labor Laws, wages are retained for the worker on business trip. And sick leave is not paid in this case, since the temporary disability benefit is compensation for the employee's loss of earnings due to his illness (actual suspension from work) [12].

In addition, it is not allowed to send an employee who is currently on vacation on a business trip. At the same time, if the employer desperately needs to send a vacationer, first of all, with his consent, an order should be issued to recall such an employee from vacation, and only then send him on a business trip [19].

In the event that an employee is sent on a business trip, the employer must provide him with funds. Guarantees and compensations for business trips are defined in Art. 121 of the Code of Labor Lawsand Instruction No. 59 [11, 12]. Accordingly, failure to provide an employee with an advance payment is a violation of labor law, and in order to avoid such a problem, the employer must give the employee a cash advance before leaving on a business trip within the amount determined for travel, rental housing and daily expenses [11].

For budgetary institutions, the amount of per diems is determined by Resolution No. 98 [14]: within Ukraine - UAH 60 ; abroad-depending on the country of travel, the amount in US dollars - for renting a living space per day - no more than UAH 600,00 [20].
The employee has all reasons to refuse a business trip if he/she does not receive at least part of the funds for the business trip in advance. Therefore, the management of the institution needs to take care of the availability of approved allocations according to the Code of Economic Classification of Expenses 2250 "Business trip expenses" in advance in order to provide the employee with funds at least partially [21].

When returning from a business trip, the employee submits to the accounting department a report on the use of funds issued for a business trip or on condition of accountability, the so-called business trip expense report. The accountant of a public sector institution checks in the Report: the availability of all necessary details: the correctness of the correspondence of accounts for writing off business trip expenses; the correspondence of the data of Transaction Memo No. 8 "Accumulative Sheet for Settlements with Accountable Persons" to the data of reports, and the data of analytical accounting (Transaction Memo No. 8) - to the data of the Nominal Ledger. Business trip expenses are reflected in the accounting as of the date of approval by the head of the enterprise of the business trip expense report [22].

When reflecting in the accounting the records of operations for issuing an advance payment for a business trip and approving expenses for the Report, one should be guided by:

1. The law of July 16, 1999 No. 996-XIV “On Accounting and Financial Reporting in Ukraine" [23]. 
2. National Regulation (Standard) of Accounting in the Public Sector 124 “Income" [24].

3.National Regulation (Standard) of Accounting in the Public Sector 130 "Impact of changes in exchange rates" [25].

4. National Regulation (Standard) of Accounting in the Public Sector 130135 “Expenses” [26].

5. Chart of Accounts for bookkeeping in the public sector, approved by order of Ministry of Finance of December 31, 2013 No. 1203 (hereinafter referred to as the Chart of Accounts No. 1203); the Procedure for applying the Chart of Accounts for bookkeeping in the public sector, approved by order of Ministry of Finance of December 29, 2015. No. 1219 (hereinafter referred to as the Order No. 1219, Procedure No. 1219) $[27,28]$.

6. Typical correspondence of accounting subaccounts to reflect transactions with assets, capital and liabilities by managers of budgetary funds and state trust funds, approved by Order No. 1219 (hereinafter referred to as the Typical Correspondence No. 1219) [29].

The issuance of an advance payment for a business trip to employees of public sector institutions, as well as the approval of expenses under the Report on the use of funds issued for a business trip or on condition of accountability [30], is carried out using:
1. subaccount 2116 "Accounts receivable for settlements with accountable persons", because in accordance with Order No. 1219, it is the account of settlements with employees of a public sector entity for an advance payment for business needs and business trip expenses. The issuance of funds to the accountable persons for economic needs or business trip expenses is reflected as an increase in debt, and the acceptance of the report and the return by the accountable person of the balance of the advance payment to the cashier is reflected as a decrease in such debt [28].

2. subaccounts of account 22 "Cash and cash equivalents", which, in accordance with Order No. 1219, summarizes information on the availability and movement of cash, cash documents (in national and foreign currencies) that are in the cash desk of a public sector entity and on business trip costs (Table 2 ).

3. subaccounts of account 23 "Cash on accounts", with the help of which information on the availability and movement of cash held in accounts with banks and Treasury bodies is taken into account and summarized. The debit of this account reflects the receipt of funds to the accounts in banks and Treasury bodies, the credit reflects their use (Table 3 ).

Table 2 Accounting of cash flows at the cash desk of a public sector institution intended for settlements with persons sent on a business trip

\begin{tabular}{|c|c|c|}
\hline \multirow{2}{*}{ Operation subject } & \multicolumn{2}{|c|}{ Correspondence of accounts } \\
\hline & DB & CR \\
\hline \multicolumn{3}{|l|}{ Business trips within Ukraine } \\
\hline Appropriations received & 2313 & 7011 \\
\hline Cash received & 2211 & 2313 \\
\hline An advance payment in national currency is issued from the institution's cash desk & 2116 & 2211 \\
\hline $\begin{array}{l}\text { Approved Report for the amount of: } \\
\text { - issued advance payment } \\
\text { - cost overruns }\end{array}$ & 8411 & $\begin{array}{l}2116 \\
6415\end{array}$ \\
\hline Reimbursed amount of the cost overrun to an employee & 6415 & 2211 \\
\hline $\begin{array}{l}\text { At the end of the reporting period there are closed: } \\
\text { - income account } \\
\text { - expense account }\end{array}$ & $\begin{array}{l}7011 \\
5511\end{array}$ & $\begin{array}{l}5511 \\
8411\end{array}$ \\
\hline \multicolumn{3}{|l|}{ Business trips abroad } \\
\hline Appropriations received & 2313 & 7011 \\
\hline $\begin{array}{l}\text { The bank's funds are transferred for the purchase of foreign currency (at the official exchange rate } \\
\text { of the NBU on the corresponding date) }\end{array}$ & 2117 & 2313 \\
\hline $\begin{array}{l}\text { Foreign currency is purchased and reflected in the foreign currency account of the institution } \\
\text { opened with the bank }\end{array}$ & 2311 & 2117 \\
\hline The costs of the bank's services for the purchase of foreign currency are included in the expenses & 8411 & 2117 \\
\hline Foreign currency is received in cash & 2212 & 2311 \\
\hline An advance payment in foreign currency is issued from the cash desk of the institution & 2116 & 2212 \\
\hline $\begin{array}{l}\text { Approved Report for the amount of: } \\
\text { - issued advance payment } \\
\text { - cost overruns }\end{array}$ & 8411 & $\begin{array}{l}2116 \\
6415\end{array}$ \\
\hline $\begin{array}{l}\text { The rest of the money of the unused advance payment in foreign currency is returned to the } \\
\text { cashier by the employee }\end{array}$ & 2212 & 2116 \\
\hline The exchange rate difference from the increase in the exchange rate is accrued & 2212 & 7411 \\
\hline Unused foreign currency is credited to the institution's foreign currency account & 2311 & 2212 \\
\hline $\begin{array}{l}\text { At the end of the reporting period there are closed: } \\
\text { - income account } \\
\text { - expense account }\end{array}$ & $\begin{array}{l}7011,7411 \\
5511\end{array}$ & $\begin{array}{l}5511 \\
8411\end{array}$ \\
\hline
\end{tabular}

Source: [31] 
Електронне наукове фахове видання з економічних наук «Modern Economics», №25 (2021), 86-91 https://modecon.mnau.edu.ua | ISSN 2521-6392

Table 3 Accounting of cash flows in the accounts of a public sector institution intended for settlements with persons sent on a business trip

\begin{tabular}{|c|c|c|}
\hline \multirow{2}{*}{ Operation subject } & \multicolumn{2}{|c|}{ Correspondence of accounts } \\
\hline & DB & CR \\
\hline \multicolumn{3}{|l|}{ Business trips within Ukraine } \\
\hline Appropriations received & 2313 & 7011 \\
\hline $\begin{array}{l}\text { An advance payment in national currency is transferred to the employee's card } \\
\text { account, sent on a business trip }\end{array}$ & 2116 & 2313 \\
\hline $\begin{array}{l}\text { Approved Report for the amount of: } \\
\text { - issued advance payment } \\
\text { - cost overruns }\end{array}$ & 8411 & $\begin{array}{l}2116 \\
6415\end{array}$ \\
\hline The employee is reimbursed the amount of cost overruns & 6415 & 2313 \\
\hline $\begin{array}{l}\text { At the end of the reporting period there are closed: } \\
\text { - income account } \\
\text {-expense account }\end{array}$ & $\begin{array}{l}7011 \\
5511\end{array}$ & $\begin{array}{l}5511 \\
8411\end{array}$ \\
\hline \multicolumn{3}{|l|}{ Business trips abroad } \\
\hline Appropriations received & 2313 & 7011 \\
\hline $\begin{array}{l}\text { The bank's funds are transferred for the purchase of foreign currency (at the } \\
\text { official exchange rate of the NBU on the corresponding date) }\end{array}$ & 2117 & 2313 \\
\hline $\begin{array}{l}\text { Foreign currency is purchased and reflected in the foreign currency account of the } \\
\text { institution opened with the bank }\end{array}$ & 2311 & 2117 \\
\hline $\begin{array}{l}\text { The costs of the bank's services for the purchase of foreign currency are included } \\
\text { in the expenses }\end{array}$ & 8411 & 2117 \\
\hline $\begin{array}{l}\text { The advance payment in foreign currency is transferred to the card account of the } \\
\text { employee sent on a business trip }\end{array}$ & 2116 & 2311 \\
\hline $\begin{array}{l}\text { Approved report for the amount of: } \\
\text { - issued advance payment } \\
\text { - cost overruns }\end{array}$ & 8411 & $\begin{array}{l}2116 \\
6415\end{array}$ \\
\hline $\begin{array}{l}\text { The employee is reimbursed the amount of cost overruns in UAH equivalent at } \\
\text { the rate of the NBU }\end{array}$ & 6415 & 2313 \\
\hline $\begin{array}{l}\text { Revalued accounts payable are attributed to expenses according to the approved } \\
\text { Report in case of increase of the NBU exchange rate as of the respective date }\end{array}$ & 8415 & 6415 \\
\hline $\begin{array}{l}\text { Revalued accounts payable are attributed to income according to the approved } \\
\text { Report in case of decrease in the NBU exchange rate as of the respective date }\end{array}$ & 6415 & 7411 \\
\hline $\begin{array}{l}\text { Approved Report for the amount of: } \\
\text { - issued advance payment } \\
\text { - cost overruns }\end{array}$ & $\begin{array}{l}7011,7411 \\
5511\end{array}$ & $\begin{array}{l}5511 \\
8411\end{array}$ \\
\hline
\end{tabular}

Source: [31]

When accepting the Report after the execution of the instructions of the management on the basis of supporting documents, the following entries are made in the accounting: DB 15 "Inventory", 1812 "Expendables \& consumables", 1816 "Other non-financial assets", 8411 CR 2116 [31].

With the growing crisis in the national economy caused by the COVID-19 pandemic, efficient spending of budget funds is becoming the main task of the activities of institutions and enterprises operating in the public sector. The lack of budgetary resources forces them to search for ways to optimize the costs of these entities, including business trip expenses. One of these ways may be the introduction of performance audit by public sector entities.

Expenditure performance audit is an integral part of the regulatory system, the purpose of which is to identify deviations from accepted standards and violations of the principles of legality, efficiency and economy in the expenditure of material resources of public institutions and enterprises [32]. The process of organizing and conducting a performance audit is very similar to that of a financial audit.

Implementation of performance audit will help an institution or enterprise operating in the public sector to achieve its goals by using a systematic, disciplined approach to assessing and improving the effectiveness of processes for managing and controlling expenditures, including business trip expenses.

Conclusions. Our research allows us to conclude that documenting and recording business trip expenses is a rather complicated accounting procedure, which is regulated in a complicated manner by both the relevant national legislation and an internal document - an order on accounting policy - in the form of a detailed approach to the specified accounting object, taking into account the practice of carrying out such business trips in the institution.

To minimize business trip expenses and use financial resources as efficiently as possible, there is an urgent need for institutions operating in the public sector to implement a performance audit mechanism. However, at 
present, the system of internal control of executive bodies under local councils is not introduced. Most institutions and enterprises operating in the public sector remain outside independent external control, which is limited to inspection measures, that is, verification of compliance with the law.
Absolute and timely documentation of the accounting of business trip expenses within the framework of regulatory legal acts is a guarantee of compliance with accounting policies, reliability of accounting and reporting, accounting for settlements with accountable persons.

\section{References:}

1. Svirko, S. V. \& Farion, A. I. (2012). Subjects and Objects of Accounting in the Public Sector of Ukraine in the Context of Current Domestic Legislation. Independent auditor, 2 (IV), 36-42.

2. Atamas, P. Y. (2009). Accounting in Budgetary Institutions: study guide [for students of higher educational institutions]. Kyiv: Center for Educational Literature.

3. Luchko, M. R., Zorii, N. M. \& Khorunzhak, N. M. (2015). Control in the Public Sector of the Economy: study guide. Ternopil: Ternopil National Economic University.

4. Khorunzhak, N. M. (2013). Theory and Methodology of Accounting in Budgetary Institutions in the Conditions of Informatizationof Society: monograph. Ternopil: Ternopil National Economic University.

5. Luhcko, M., Sosiuk, S., Khorunzhak, N., Benko, I. (2017). Accounting in Ukraine under Implementation of the European Legislation. Ternopil : TNEU.

6. Dzhoha, R. T. (2003). Accounting in Budgetary Institutions: textbook. Kyiv: Kyiv National Economic University.

7. Bilukha, M. T. (2003). Standards of State Financial Control. Accounting and auditing, 11. P. 45-48

8. Duda, T. T. (2014). Estimated Aspects of Accounting for Business Trip Expenses Abroad. Economic sciences, 3(212), 156-160.

9. Len, V. S. (2006). Organization of Accounting: textbook. Kyiv: Center for Educational Literature.

10. Melnyk, N. B. (2014). Calculations for Business Trips in the System of Elements of the Method of Accounting. Current problems of the region's development, 9, 65-70.

11. Instruction on Business Trips within Ukraine and Abroad: Order of Ministry of Finance of Ukraine of March 13, 1998 No. 59. Date of update 15.09.2017. URL: https://zakon.rada.gov.ua/laws/show/z0218-98.

12. Code of Labor Laws of Ukraine No. 322-VIII of December 10, 1971. URL: https://zakon.rada.gov.ua/laws/show/322-08\#Text

13. On Public Service: Law of Ukraine of December 10, 2015 No. 889. URL: https://zakon.rada.gov.ua/laws/show/889-19\#Text.

14. On the amounts and composition of business trip expenses of civil servants, as well as other persons sent on a business trip by enterprises, institutions and organizations, which are fully or partially supported (financed) from budget funds : Resolution of the Cabinet of Ministers of Ukraine of 02.02.2011 No.98. URL: https://zakon.rada.gov.ua/laws/show/98-2011.

15. Code of Ukraine on Administrative Offenses No.80731-Xof December 07, 1984. URL: https://zakon.rada.gov.ua/laws/show/80731-10\#Text.

16. Business Trip: the Nuances. URL: https://i.factor.ua/ukr/journals/ds/2018/november/issue-11/article-40653.html.

17. On Business Trips: a Letter from the Ministry of Finance of 20.01.2007 No. 31-18030-07-10/854. URL: https://zakon.rada.gov.ua/rada/show/v_854201-07\#Text

18. Regarding Problematic Issues of Working Time Accounting: Letter of Ministry of Social Policy of 15.11.2013 No. 656/18/99-13. URL: https://zakon.rada.gov.ua/rada/show/v0656739-13\#Text

19. Annual Leave: Highlights. Taxes and accounting. 2017. No. 32. p. 34.

20. Maximum Per Diem Expensesfor Public Sector Employees 2020. Accountant.ua: website. URL: https://buh.ligazakon.net/aktualno/7269_dobov-2020

21. Verkhohliad, O. How to Send an Employee on a Business Trip: From Ordering to Reporting. ibuhgalter.net :website. URL: https://ibuhgalter.net/ru/material/171/3602

22. Syrtseva, S. V., Cheban, Y. Y., Braslavska, I. M. (2019). Settlements with accountable persons in budgetary institutions: features of accounting and control. Modern Economics, 18(2019), 189-196. DOI: https://doi.org/10.31521/modecon.V18(2019)-28.

23. On Accounting and Financial Reporting in Ukraine: Law of Ukraine of July 16, 1999 No. 996-XIV.Date of update 14.11.2020. URL: https://zakon.rada.gov.ua/laws/show/996-14\#Text.

24. National Regulation (Standard) of Accounting in the Public Sector 124 "Income": Order of Ministry of Finance of Ukraine of February 7, 2013 No.73. URL: https://zakon.rada.gov.ua/laws/show/z0089-11\#Text.

25. National Regulation (Standard) of Accounting in the Public Sector 21 "Impact of changes in exchange rates": Order of Ministry of Finance of Ukraine of August 10, 2000 No. 193. URL: https://zakon.rada.gov.ua/laws/show/z0515-00\#Text.

26. National Regulation (Standard) of Accounting in the Public Sector 135 "Expenses": Order of Ministry of Finance of Ukraine of May 18, 2012 No. 568. URL: https://zakon.rada.gov.ua/laws/show/z0903-12\#Text.

27. On approval of the Chart of Accounts in the public sector: Order of Ministry of Finance of Ukraine of December 31, 2013 No. 1203. URL: https://zakon.rada.gov.ua/laws/show/z0161-14\#Text.

28. Procedure for application of the Chart of Accounts in the public sector: order of Ministry of Finance of Ukraine of December 29,2015 No. 1219. URL: http://search.ligazakon.ua/I_doc2.nsf/link1/RE28215Z.html.

29. Typical correspondence of accounting subaccounts to reflect transactions with assets, capital and liabilities by managers of budgetary funds and state trust funds: order of Ministry of Finance of Ukraine dated December 29, 2015 No.1219. Date of update URL: https://zakon.rada.gov.ua/laws/show/z0086-16.

30. On approval of the form of the Report on the use of funds issued for business trips or on condition of accountability, and the Procedure for its compilation of 28.09.15 No.841. URL: https://zakon.rada.gov.ua/laws/show/z1248-15\#Text

31. Liashenko, A. Business Trip Expenses: Nuances of Accounting.URL: URL: https://uteka.ua/ua/publication/budget-13-byudzhet-buxgalterskijuchet-otchetnost-i-kaznachejskoe-obsluzhivanie-52-rasxody-na-komandirovku-nyuansy-ucheta

32. Spodaryk, V. M., Khotnianska, N. Y. Performance Audit is a New Form of Public Financial Control in Ukraine. URL: https://dspace.uzhnu.edu.ua/jspui/bitstream/lib/7623/1/\%D0\%90\%D0\%A3\%D0\%86.pdf. 